\title{
Nutritional value of Brazilian distillers dried grains with solubles for pigs as determined by different methods
}

\author{
Anderson Corassa ${ }^{1 *}$, Iziz Paula Anhõn da Silva Lautert ${ }^{1}$, Douglas dos Santos Pina ${ }^{1}$, Charles \\ Kiefer $^{2}$, Ana Paula Silva Ton ${ }^{1}$, Claudia Marie Komiyama ${ }^{1}$, Alessandro Borges Amorim ${ }^{3}$, \\ Alexandre de Oliveira Teixeira ${ }^{4}$
}

\footnotetext{
${ }^{1}$ Universidade Federal de Mato Grosso, Instituto de Ciências Agrárias e Ambientais Sinop, MT, Brazil.

${ }^{2}$ Universidade Federal do Mato Grosso do Sul, Faculdade de Medicina Veterinária e Zootecnia, Campo Grande, MS, Brazil.

${ }^{3}$ Universidade Federal do Mato Grosso, Instituto de Ciências Agrárias e Tecnológicas, Rondonópolis, MT, Brazil.

${ }^{4}$ Universidade Federal de São João del-Rei, Departamento de Zootecnia, São João del-Rei, MG, Brazil.
}

\begin{abstract}
The objective of this study was to determine the digestibility coefficient (DC) of nutrients and the digestible energy (DE), and metabolizable energy (ME) values of distillers dried grains with solubles (DDGS) produced in Brazil by different methods. Eight barrows with $23.3 \pm 4.1 \mathrm{~kg}$ were housed in metabolic cages in a randomized block design and fed diets containing $0,200,400$, and $600 \mathrm{~g} \mathrm{~kg}^{-1}$ of corn DDGS. We determined the digestibility of dry matter (DM), organic matter (OM), crude protein (CP), ether extract (EE), mineral matter (MM), neutral detergent fiber (NDF), and gross energy (GE) by the total collection (TC) and chromium oxide marker (Cr) methods. Distillers dried grains with solubles provided the respective DM, OM, CP, EE, MM, NDF, and GE values of 910, 863, 286, 66.9, 46.8, $500 \mathrm{~g} \mathrm{~kg}^{-1}$, and 4,780 $\mathrm{kcal} \mathrm{kg}^{-1}$. The DE and ME values of DDGS were 3,739 and 3,401 kcal kg-1 and 3,691 and 3,213 $\mathrm{kcal} \mathrm{kg}^{-1}$ as determined by TC and Cr methods, respectively. The growing inclusion of DDGS did not affect the DE or ME values. The digestibility coefficients of DM, OM, CP, EE, MM, and NDF were $767,765,827,691,883$, and $821 \mathrm{~g} \mathrm{~kg}^{-1}$, respectively, by the total collection method. The Cr underestimated the values of all variables compared with TC method. Levels up to $600 \mathrm{~g} \mathrm{~kg}^{-1}$ of the test ingredient do not influence the DE and ME of DDGS, but compromises the digestibility coefficients of DM, OM, and NDF.
\end{abstract}

Key Words: corn ethanol, digestibility, DDGS, marker, metabolizability, total feces collection

\section{Introduction}

Distillers dried grains with solubles (DDGS) are byproducts from ethanol production whose chemical properties allow for a broad use in swine diets. Studies conducted with DDGS produced in the USA (Anderson et al., 2012), China (Li et al., 2015), and Europe (Cerisuelo et al., 2012) have demonstrated the large variety in their composition and nutritional value. In Brazil, ethanol is commonly obtained from sugarcane and only recently has it been produced from corn, especially in regions where the supply of this cereal is abundant.

Received: May 16, 2017

Accepted: August 7, 2017

*Corresponding author: anderson_corassa@ufmt.br

http://dx.doi.org/10.1590/S1806-92902017000900005

How to cite: Corassa, A.; Lautert, I. P. A. S.; Pina, D. S.; Kiefer, C.; Ton, A. P. S.; Komiyama, C. M.; Amorim, A. B. and Teixeira, A. O. 2017. Nutritional value of Brazilian distillers dried grains with solubles for pigs as determined by different methods. Revista Brasileira de Zootecnia 46(9):740-746.

Copyright (C) 2017 Sociedade Brasileira de Zootecnia. This is an Open Access article distributed under the terms of the Creative Commons Attribution License (http://creativecommons.org/licenses/by/4.0/), which permits unrestricted use, distribution, and reproduction in any medium, provided the original work is properly cited.
Reduced starch contents and elevated concentrations of protein, ether extract, and fiber make DDGS a potential ingredient to replace the corn and soybean meal in pig diets; however, its nutritional composition - especially in terms of energy - must be determined for its proper use. Several factors can affect the composition of DDGS, e.g., the quality of grains, analytical methods, proportion of solubles, and processing method. Nevertheless, the composition of the DDGS from corn produced in Brazil has not yet been determined.

In feedstuff digestibility assays, the most frequently employed methods are total feces and urine collection and indigestibility markers such as chromium oxide. According to Sakomura and Rostagno (2007), the main limitation of the total collection method is control during the collection of feces and urine samples without contaminations such as shedding of skin, hair, and feed, which may interfere with the determination of the energy content of a feedstuff. On the other hand, the use of markers does not require quantification of intake and feces and a partial collection of the sample can be performed to reduce possible contamination. However, the use of this method requires uniform mixture into the diet and standardization 
for chemical analyses, which may lead to a significant variability of results.

It has thus been hypothesized that the energy and nutritional values of DDGS produced are distinct and may be influenced by the evaluation method. Therefore, the present study was conducted to determine the digestible energy, metabolizable energy, and nutritional values of DDGS produced in Brazil, using different methods.

\section{Material and Methods}

The experiment was conducted in Sinop, Mato Grosso, Brazil ( $\left.11^{\circ} 51^{\prime} 41^{\prime \prime} \mathrm{S}, 5^{\circ} 28^{\prime} 57^{\prime \prime} \mathrm{W}\right)$, complying with the ethical principles of animal experimentation adopted by the National Council for the Control of Animal Experimentation, and after being approved by the Committee of Ethics in Animal Use (case no. 23108.700673/14-4).

Eight genetically homogenous barrows originating from industrial crosses, with $23.3 \pm 4.1 \mathrm{~kg}$, were distributed individually into metabolic cages. We adopted a randomized block design with four treatments and six replicates that were distributed along three 12-day periods, consisting of seven days for adaptation to the diet and five days for collection. The animal weight and the periods were used to characterize the blocks.

Treatments were composed of a control diet based on corn and soybean meal (Table 1) formulated to meet the recommendations of Rostagno et al. (2011) and containing

Table 1 - Composition and calculated nutritional values of control $\operatorname{diet}$ (as-fed basis)

\begin{tabular}{|c|c|}
\hline Ingredient $\left(\mathrm{g} \mathrm{kg}^{-1}\right)$ & Control diet \\
\hline Corn & 604.8 \\
\hline Soybean meal & 302.6 \\
\hline Rice bran & 30.0 \\
\hline Soy oil & 18.9 \\
\hline Calcitic limestone & 5.2 \\
\hline Dicalcium phosphate & 17.5 \\
\hline Vitamin-mineral mix ${ }^{1}$ & 10.0 \\
\hline Common salt & 4.6 \\
\hline L-lysine & 1.5 \\
\hline Chromium oxide & 5.0 \\
\hline Total & 1000 \\
\hline \multicolumn{2}{|l|}{ Calculated nutrient content $\left(\mathrm{g} \mathrm{kg}^{-1}\right)$} \\
\hline Metabolizable energy swine ( $\mathrm{kcal} \mathrm{kg}^{-1}$ ) & 3,230 \\
\hline Crude protein & 189.9 \\
\hline Calcium & 7.2 \\
\hline Available phosphorus & 3.6 \\
\hline Sodium & 2.0 \\
\hline Digestible lysine & 10.1 \\
\hline \multicolumn{2}{|c|}{$\begin{array}{l}{ }^{1} \text { Composition of the supplement per kg of diet: vitamin A, } 13750 \mathrm{IU} \text {; vitamin B1, } \\
2 \mathrm{mg} \text {; vitamin B2, } 1.25 \mathrm{mg} \text {; vitamin B6, } 4 \mathrm{mg} \text {; vitamin B12, } 4.5 \mathrm{mcg} \text {; vitamin D3, } \\
3000 \mathrm{IU} \text {; vitamin E, } 75 \mathrm{IU} \text {; vitamin K3, } 6.25 \mathrm{mg} \text {; nicotinic acid, } 50 \mathrm{mg} \text {; pantothenic } \\
\text { acid, } 30 \mathrm{mg} \text {; folic acid, } 0.625 \mathrm{mg} \text {; cobalt, } 1.25 \mathrm{mg} \text {; copper, } 25 \mathrm{mg} \text {; iron, } 150 \mathrm{mg} \text {; } \\
\text { zinc, } 200 \mathrm{mg} \text {; manganese, } 75 \mathrm{mg} \text {; selenium, } 0.7 \mathrm{mg} \text {; iodine, } 2 \mathrm{mg} \text {; coline, } 250 \mathrm{mg} \text {; } \\
\text { biotin, } 25 \mathrm{mcg} \text {. }\end{array}$} \\
\hline
\end{tabular}

corn DDGS in an isometric substitution of 200, 400, and $600 \mathrm{~g} \mathrm{~kg}^{-1}$ of the control diet (Table 2), according to the methodology described by Sakomura and Rostagno (2007). To evaluate the digestibility, we simultaneously employed the total feces and urine collection (TC) and chromium oxide $\left(\mathrm{Cr}_{2} \mathrm{O}_{3}\right)$ indigestibility marker $(\mathrm{Cr})$ methods.

The distillers dried grains with solubles used here were obtained from ethanol production using corn as raw material (USIMAT Alcohol Distillery Ltd; Campos de Julio, MT, Brazil). Analyses for the chemical composition of diets and DDGS were performed following Silva and Queiroz (2002) (Table 2).

In the adaptation period, the diet was supplied ad libitum and orts were recorded for a later calculation of intake based on the metabolic weight $\left(\mathrm{LW}^{0.75}\right)$. To prevent losses and facilitate intake, the diets were weighed and moistened at a 1:1 ratio and supplied twice daily (07:30 and 17:30 h).

Feces and urine were collected once daily, in the morning. The material was weighed and homogenized and then samples of $200 \mathrm{~g} \mathrm{~kg}^{-1}$ of the total were collected, packed in plastic bags, identified, and stored in a freezer $\left(-10^{\circ} \mathrm{C}\right)$. Urine was filtered as it was excreted using a filter tissue placed in a funnel beneath the urine collection box and then collected in plastic buckets containing $10 \mathrm{~mL} \mathrm{HCl} \mathrm{(1:1).} \mathrm{The}$ total urine volume of each sample was counted using a 5-mL graduated beaker from which aliquots of $20 \%$ were taken for sampling, packaged, and stored in a freezer.

At the end of the collection period, feces samples were thawed, weighed, homogenized, and pre-dried in a forced-air oven at $60{ }^{\circ} \mathrm{C}$ for $72 \mathrm{~h}$ for analyses of dry matter (DM), crude protein $(\mathrm{CP})$, ether extract (EE), mineral matter (MM), neutral detergent fiber (NDF), and gross energy (GE), according to Silva and Queiroz (2002). The organic matter (OM) content was determined as the difference between the DM and MM contents. Analyses for the chromium content in the feces were undertaken by atomic absorption spectrophotometry (Willians et al., 1962). The urine samples were thawed and homogenized for the determination of total nitrogen and gross energy.

Table 2 - Chemical composition of diets and distillers dried grains with solubles (DDGS)

\begin{tabular}{lccccc}
\hline \multirow{2}{*}{ Item $\left(\mathrm{g} \mathrm{kg}^{-1}\right)$} & \multicolumn{5}{c}{ DDGS $\left(\mathrm{g} \mathrm{kg}^{-1}\right)$} \\
\cline { 2 - 5 } & 0 & 200 & 400 & 600 & \\
\hline Dry matter & 892.6 & 898.1 & 900.4 & 901.8 & 910.0 \\
Organic matter & 955.6 & 956.9 & 958.3 & 959.7 & 863.2 \\
Crude protein & 202.3 & 218.3 & 247.8 & 264.0 & 286.0 \\
Ether extrat & 42.7 & 47.5 & 52.7 & 57.3 & 66.9 \\
Mineral matter & 44.4 & 43.1 & 41.7 & 40.3 & 46.8 \\
Neutral detergente fiber & 119.9 & 195.9 & 271.9 & 348.0 & 500.4 \\
Gross energy $\left(\mathrm{kcal} \mathrm{kg}^{-1}\right)$ & 3984 & 4153 & 4331 & 4557 & 4780 \\
\hline
\end{tabular}


The digestibility coefficients (DC), digestible nutrients, and digestible energy (DE), metabolizable energy (ME), and their corrections for the nitrogen content (DEn and MEn) were determined according to Sakomura and Rostagno (2007).

The experiment was conducted as a randomized block design in a split-plot arrangement, with analysis of variance performed according to the statistical model below:

$$
\text { Yijk }=\mu+D i+P j+M k+D i \times M k+\varepsilon i j+\varepsilon i j k,
$$

in which Yijk = observation of the effect of DDGS level i, in period $\mathrm{j}$, using the digestibility assessment method $\mathrm{k}$; $\mu=$ overall mean; $\mathrm{Di}=$ effect of DDGS inclusion level $(\mathrm{i}=0$, 200, 400, or $\left.600 \mathrm{~g} \mathrm{~kg}^{-1}\right) ; \mathrm{Pj}=$ experimental period $(\mathrm{j}=1$, 2 , or 3); $\mathrm{Mk}=$ effect of the digestibility assessment method ( $\mathrm{k}=$ total collection or marker); $\mathrm{Di} \times \mathrm{Mk}=$ interaction effect between the DDGS level $\mathrm{i}$ and the digestibility assessment method k; $\varepsilon i j=$ random error associated with the plot; and $\varepsilon i j k=$ random error associated with the subplot.

Effects related to the DDGS level were evaluated by decomposing the sum of squares of treatments into orthogonal contrasts to assess the linear and quadratic effects. The F test was used for the evaluation of collection methods.

The data were subjected to the mixed procedure of the SAS software (Statistical Analysis System, version 6.0), considering the $5 \%$ probability level. For the analysis of final weight and daily feed intake, we used the initial weight as a co-variable. Data pertaining to digestibility and metabolizability coefficients, digestible nutrients, digestible and metabolizable energy corrected for the nitrogen excretion of the diets, and of DDGS were subjected to an ANOVA considering the effects of the digestibility assessment method and the interaction between these and the DDGS inclusion level. The metabolizable energy value was estimated by regression analysis (Adeola and Ileleji, 2009) of ME intake (kcal) associated with DDGS vs. DDGS intake (g) by the TC and Cr methods.

\section{Results}

We did not detect interaction effects between the digestibility assessment methods and DDGS inclusion levels on the energy values of DDGS (Table 3). Digestible energy, DEn, ME, MEn, DE:ME, and DEn:MEn of DDGS were not influenced by the different inclusion levels of this ingredient $(\mathrm{P}>0.05)$; however, the total collection method generated higher values in comparison with the marker method, except for DEn. The slope of the linear relationship between ME intake and DDGS intake (Figure 1) shows that the $\mathrm{TC}$ and $\mathrm{Cr}$ methods generated different ME values (3,668 and 3,213 $\mathrm{kcal} \mathrm{kg}^{-1}$, respectively).

No interaction effect between the digestibility assessment methods and DDGS inclusion levels was observed on the digestibility coefficients of DDGS, except for NDF (Table 4). The digestibility coefficients of DM, OM, and NDF of DDGS decreased as the inclusion

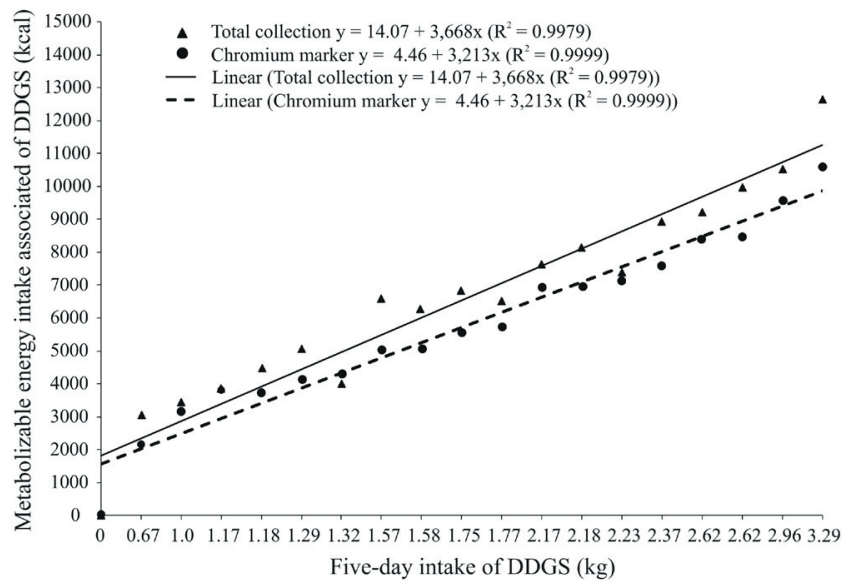

DDGS - distillers dried grains with solubles; ME - metabolizable energy.

Figure 1 - Equations of ME of glycerin obtained from intake of ME ( $\left.\mathrm{kcal} \mathrm{kg}^{-1}\right)$, associated to DDGS vs. DDGS intake (g) for five days determined by the total collection and chromium marker digestibility methods.

Table 3 - Values and relations of energy of DDGS for pigs with different DDGS levels determined by the total collection (TC) and chromium marker $(\mathrm{Cr})$ digestibility methods

\begin{tabular}{|c|c|c|c|c|c|c|c|c|c|}
\hline & \multicolumn{3}{|c|}{ DDGS $\left(\mathrm{g} \mathrm{kg}^{-1}\right)$} & \multicolumn{2}{|c|}{ Digestibility method } & \multicolumn{4}{|c|}{ Significance $^{1}$} \\
\hline & 200 & 400 & 600 & $\mathrm{TC}$ & $\mathrm{Cr}$ & $\mathrm{L}$ & Q & Digestibility method & SEM \\
\hline DE $\left(\mathrm{kcal} \mathrm{kg}^{-1}\right)$ & 3,556 & 3,567 & 3,587 & 3,739 & 3,401 & 0.7980 & 0.9685 & 0.0008 & 51.29 \\
\hline DEn $\left(\mathrm{kcal} \mathrm{kg}^{-1}\right)$ & 3,436 & 3,440 & 3,406 & 3,471 & 3,384 & 0.7727 & 0.8642 & 0.2771 & 39.95 \\
\hline $\operatorname{ME}\left(\mathrm{kcal} \mathrm{kg}^{-1}\right)$ & 3,445 & 3,447 & 3,465 & 3,691 & 3,213 & 0.8618 & 0.9411 & $<0.0001$ & 56.64 \\
\hline $\operatorname{MEn}\left(\mathrm{kcal} \mathrm{kg}^{-1}\right)$ & 3,404 & 3,372 & 3,371 & 3,562 & 3,203 & 0.7859 & 0.8877 & 0.0001 & 48.55 \\
\hline ME:DE & 0.9688 & 0.9650 & 0.9657 & 0.9881 & 0.9449 & 0.3926 & 0.5122 & $<0.0001$ & 0.027 \\
\hline MEn:DEn & 0.9879 & 0.9842 & 0.9842 & 1.0259 & 0.9449 & 0.6196 & 0.7719 & $<0.0001$ & 0.007 \\
\hline
\end{tabular}

DDGS - distillers dried grains with solubles; DE - digestible energy; DEn - digestible energy corrected for nitrogen balance; ME - metabolizable energy; MEn - metabolizable energy corrected for nitrogen balance; L - linear effect; Q - quadratic effect; SEM - standard error of the mean.

${ }^{1}$ Significance level $\mathrm{P}<0.05$. 
of this test feedstuff in the diets was increased, whereas the digestibility coefficients of $\mathrm{CP}, \mathrm{EE}$, and $\mathrm{MM}$ were not influenced by the inclusions. In all DDGS fractions evaluated here, the DC were higher when determined by total collection as compared with the marker method.

There were no interaction effects between collection methods and DDGS levels on the digestible fractions of the feed (Table 5). The digestible contents of DM, OM, EE, and NDF decreased linearly as the inclusion of DDGS in the diets was elevated, whereas the digestible content of $\mathrm{CP}$ was increased. The digestible MM content was not changed by DDGS inclusion. All digestible fractions showed higher values when determined by the total collection method in relation to the marker method.

\section{Discussion}

The different inclusion levels of the test ingredient did not influence the determination of the energy values of DDGS. This finding agrees with Graham et al. (2014a), who calculated the caloric efficiencies, based on ADFI $\times$ dietary energy ( $\mathrm{Mcal} \mathrm{\textrm {kg } ^ { - 1 }}$ ) divided by total body weight gain, and observed that $\mathrm{DE}$ and $\mathrm{ME}$ did not change with inclusions of $0,250,300$, and $450 \mathrm{~g} \mathrm{~kg}^{-1}$ of DDGS.
The gross energy $\left(4,780 \mathrm{kcal} \mathrm{kg}^{-1}\right)$ of the corn DDGS produced in Brazil evaluated in this study was lower than that of the seven samples evaluated by Anderson et al. (2012) $\left(5,076\right.$ to $\left.5,550 \mathrm{kcal} \mathrm{kg}^{-1}\right)$, but within the range of the ten samples evaluated by Pedersen et al. (2007) $\left(4,571\right.$ to $\left.4,851 \mathrm{kcal} \mathrm{kg}^{-1}\right)$ and 25 samples tested by $\mathrm{Li}$ et al. (2015) $\left(4,763\right.$ to $\left.5,371 \mathrm{kcal} \mathrm{kg}^{-1}\right)$. In the evaluation of DE, the $3,739 \mathrm{kcal} \mathrm{kg}^{-1}$ found with the total collection method was lower than the 3,947 to $4,593 \mathrm{kcal} \mathrm{kg}^{-1}$ found by Pedersen et al. (2007), but close to the lowest values found by Anderson et al. (2012) (3,705 to 4,332 kcal kg-1); it was, however, within the range found by Li et al. (2015) $(3,255$ to $\left.4,103 \mathrm{kcal} \mathrm{kg}^{-1}\right)$. The ME value of 3,691 $\mathrm{kcal} \mathrm{kg}^{-1}$ of the present study is near the lowest values found by Pedersen et al. (2007) $\left(3,674\right.$ to $\left.4,336 \mathrm{kcal} \mathrm{kg}^{-1}\right)$ and Anderson et al. (2012) $\left(3,650\right.$ to $\left.4,141 \mathrm{kcal} \mathrm{kg}^{-1}\right)$, but within the range found by Li et al. (2015) (2,955 to 3,899 $\left.\mathrm{kcal} \mathrm{kg}^{-1}\right)$.

The energy value of the feedstuffs is closely related to their chemical composition. Positive correlations between ether extract and GE $(r=0.92), \mathrm{DE}(\mathrm{r}=0.55)$, and ME $(\mathrm{r}=0.54)$ and negative correlations between NDF and $\mathrm{DE}(\mathrm{r}=-0.77)$ and $\mathrm{ME}(\mathrm{r}=-0.76)$ of DDGS were observed by Li et al. (2015). In this way, differences in the energy content of the DDGS investigated here and the

Table 4 - Digestibility coefficients of the chemical composition of experimental diets for pigs with different DDGS levels determined by the total collection (TC) and chromium marker $(\mathrm{Cr})$ digestibility methods

\begin{tabular}{|c|c|c|c|c|c|c|c|c|c|}
\hline \multirow{2}{*}{ DC $\left(\mathrm{g} \mathrm{kg}^{-1}\right)$} & \multicolumn{3}{|c|}{ DDGS $\left(\mathrm{g} \mathrm{kg}^{-1}\right)$} & \multicolumn{2}{|c|}{ Digestibility method } & \multicolumn{4}{|c|}{ Significance $^{1}$} \\
\hline & 200 & 400 & 600 & $\mathrm{TC}$ & $\mathrm{Cr}$ & $\mathrm{L}$ & Q & Digestibility method & SEM \\
\hline DM & 753.8 & 687.0 & 668.2 & 767.8 & 638.3 & 0.0043 & 0.3247 & $<0.0001$ & 1.67 \\
\hline $\mathrm{OM}$ & 740.7 & 689.8 & 679.4 & 765.1 & 641.6 & 0.0270 & 0.3827 & $<0.0001$ & 1.53 \\
\hline $\mathrm{CP}$ & 760.4 & 777.8 & 796.8 & 827.1 & 729.6 & 0.2522 & 0.9777 & 0.0006 & 1.47 \\
\hline $\mathrm{EE}$ & 655.9 & 610.9 & 603.0 & 691.3 & 555.2 & 0.3831 & 0.7219 & 0.0091 & 2.59 \\
\hline MM & 770.5 & 708.2 & 693.1 & 883.6 & 564.3 & 0.0664 & 0.5066 & $<0.0001$ & 3.18 \\
\hline NDF & 821.8 & 732.8 & 719.0 & 821.8 & 693.9 & 0.0140 & 0.279 & 0.0004 & 2.00 \\
\hline
\end{tabular}

DDGS - distillers dried grains with solubles; DC - digestibility coefficient; DM - dry matter; OM - organic matter; CP - crude protein; EE - ether extract; MM - mineral matter; NDF - neutral detergent fiber; L - linear effect; Q - quadratic effect; SEM - standard error of the mean.

${ }^{1}$ Significance level $\mathrm{P}<0.05$.

$\hat{\mathrm{Y}}_{\mathrm{DC}-\mathrm{DM}}=872.4242-2.4192 \mathrm{x}\left(\mathrm{R}^{2}=0.58\right) ; \hat{\mathrm{Y}}_{\mathrm{DC}-\mathrm{OM}}=870.5817-2.4328 \mathrm{x}\left(\mathrm{R}^{2}=0.57\right) ; \hat{\mathrm{Y}}_{\mathrm{DC}-\mathrm{NDF}}=836.8267-1.6682 \mathrm{x}\left(\mathrm{R}^{2}=0.28\right)$.

Table 5 - Digestibility of the chemical composition of experimental diets for pigs with different DDGS levels determined by the total collection (TC) and chromium marker (Cr) digestibility methods

\begin{tabular}{|c|c|c|c|c|c|c|c|c|c|}
\hline \multirow{2}{*}{ Digestible content $\left(\mathrm{g} \mathrm{kg}^{-1}\right)$} & \multicolumn{3}{|c|}{ DDGS $\left(\mathrm{g} \mathrm{kg}^{-1}\right)$} & \multicolumn{2}{|c|}{ Digestibility method } & \multicolumn{4}{|c|}{ Significance $^{1}$} \\
\hline & 200 & 400 & 600 & $\mathrm{TC}$ & $\mathrm{Cr}$ & $\mathrm{L}$ & Q & Digestibility method & SEM \\
\hline DM & 695.5 & 637.6 & 619.9 & 702.3 & 599.6 & 0.0041 & 0.3475 & $<0.0001$ & 1.39 \\
\hline $\mathrm{OM}$ & 721.6 & 668.6 & 654.3 & 736.5 & 626.5 & 0.0180 & 0.4127 & $<0.0001$ & 1.48 \\
\hline $\mathrm{CP}$ & 226.4 & 241.9 & 249.8 & 250.1 & 228.6 & 0.0013 & 0.5057 & 0.0004 & 0.35 \\
\hline $\mathrm{EE}$ & 45.1 & 40.7 & 39.1 & 46.2 & 37.1 & 0.0419 & 0.5732 & 0.0005 & 0.14 \\
\hline MM & 30.2 & 26.4 & 25.6 & 34.2 & 20.6 & 0.4111 & 0.4509 & $<0.0001$ & 0.15 \\
\hline NDF & 411.1 & 366.6 & 359.9 & 411.2 & 347.7 & 0.0218 & 0.3343 & 0.0059 & 0.25 \\
\hline
\end{tabular}

DM - dry matter; OM - organic matter; CP - crude protein; EE - ether extract; MM - mineral matter; NDF - neutral detergent fiber; L - linear effect; Q - quadratic effect; SEM - standard error of the mean; D - digestible.

${ }^{1}$ Significance level $\mathrm{P}<0.05$.

$\hat{\mathrm{Y}}_{\mathrm{D}-\mathrm{DM}}=753.5342-1.4881 \mathrm{x}\left(\mathrm{R}^{2}=0.42\right) ; \hat{\mathrm{Y}}_{\mathrm{D}-\mathrm{OM}}=803.5125-1.6654 \mathrm{x}\left(\mathrm{R}^{2}=0.44\right) ; \hat{\mathrm{Y}}_{\mathrm{D}-\mathrm{CP}}=163.855+0.8259 \mathrm{x}\left(\mathrm{R}^{2}=0.79\right) ; \hat{\mathrm{Y}}_{\mathrm{D}-\mathrm{EE}}=28.4458+0.1008 \mathrm{x}\left(\mathrm{R}^{2}=0.30\right) ; \hat{\mathrm{Y}}_{\mathrm{D}-\mathrm{NDF}}=397.4425-0.0431 \mathrm{x}$ $\left(\mathrm{R}^{2}=0.02\right)$. 
other sources cited in the literature are directly related to the EE $\left(66.9 \mathrm{~g} \mathrm{~kg}^{-1}\right)$ and NDF (500 $\left.\mathrm{g} \mathrm{kg}^{-1}\right)$ contents. These results are close to those reported by Li et al. (2015) (EE, 28.2 to $141.8 \mathrm{~g} \mathrm{~kg}^{-1}$; NDF, 310 to $466 \mathrm{~g} \mathrm{~kg}^{-1}$ ) and Anderson et al. (2012) (EE, 31.5 to $121 \mathrm{~g} \mathrm{~kg}^{-1}$; NDF, 334 to $\left.509.6 \mathrm{~g} \mathrm{~kg}^{-1}\right)$, but different from those found by Pedersen et al. (2007) (EE, 86 to $124 \mathrm{~g} \mathrm{~kg}^{-1}$; NDF, 200 to $266 \mathrm{~g} \mathrm{~kg}^{-1}$ ). The oil concentration of this DDGS produced in Brazil allows us to classify this ingredient as having a medium oil content, according to the NRC (2012) classification, which considers $>100 \mathrm{~g} \mathrm{~kg}^{-1}$ as high-oil, 60 to $90 \mathrm{~g} \mathrm{~kg}^{-1}$ as medium-oil, and $<40 \mathrm{~g} \mathrm{~kg}^{-1}$ as low-oil. By contrast, differences between sources in terms of ileal and total fiber digestion can contribute to differences in the digestibility of the energy in DDGS (Urriola et al., 2010). Variations in the chemical composition of different DDGS sources have also been previously reported (Anderson et al., 2012; Cerisuelo et al., 2012; Pedersen et al., 2007), suggesting it to be a critical point in their use as ingredients in animal feeding.

The variations in chemical composition between different sources may be related to characteristics of the grain and manufacturing processes (Urriola et al., 2009; Belyea et al., 2010), levels of inclusion of solubles and oil extraction (Li et al., 2015), and drying process, among others. The DDGS used in this study originated from a mill with capacity to generate ethanol also from sugarcane, which seems to be a unique feature.

The reduction of the DC (Table 4) and of the digestible fractions (Table 5) of DM, OM, and NDF with the increasing DDGS inclusion levels is likely related to the fiber fraction present in the test ingredient. According to Stein and Shurson (2009), this is explained by the fact that dietary fiber of DDGS reduces the digestibility of nutritional fractions and makes it less digestible in relation to other ingredients. Fermentation in bioethanol production removes most of the starch; thus, the fiber content in DDGS is high and less fermentable (Jha et al., 2015). As a result, fecal output increased with a reduction of DM digestibility (Widyaratne and Zijlstra, 2007). Reductions in DM digestibility as a function of an increase in DDGS in pig diets were also reported by Agyekum et al. (2016), Wang et al. (2016), Li et al. (2016), and Wahlstrom et al. (2013), who included up to $300,200,200$, and $300 \mathrm{~g} \mathrm{~kg}^{-1}$ of the ingredient, respectively. However, the digestible DM values of the DDGS in the present study are lower than the respective 902, 923, and $913.7 \mathrm{~g} \mathrm{~kg}^{-1}$ reported by Cerisuelo et al. (2012), Jacela et al. (2010), and Urriola (2009), but close to the 619 to $719 \mathrm{~g} \mathrm{~kg}^{-1}$ observed by Gutierrez et al. (2014) for different DDGS.
After starch is removed in the ethanol production process, the organic matter present in DDGS will be closely linked to the protein, oil, and fiber fractions. Therefore, the higher NDF concentrations observed in DDGS in relation to corn end up negatively influencing the organic matter digestibility, which was observed in the current study. In this sense, higher inclusions of DDGS generated diets with higher NDF contents, which led to reduced digestibility of the very NDF content and of the DM, OM, and digestible EE contents. The higher fiber concentration of DDGS compared with corn and soybean meal may influence the reduction of digestibility, despite the fact that the corn processing during ethanol production (e.g., grinding, heating, and fermentation) may modify the structure of dietary fiber, making it more digestible than the corn fiber (Le Gall et al., 2009; Graham et al., 2014b).

According to Urriola et al. (2010), over $500 \mathrm{~g} \mathrm{~kg}^{-1}$ of the total fiber in DDGS pass through the gastrointestinal tract of pigs without being fermented and only $18 \%$ of the NDF is fermented in the large intestine (Gutierrez et al., 2014). Moreover, the type of fiber present in DDGS is mostly insoluble (Pedersen et al., 2014), which may lead to a lower use of the feedstuff due to alterations in the transit time and increased intestinal endogenous losses. In this regard, Agyekum et al. (2016) reported that the NDF digestibility was lower in diets containing DDGS compared with the control diet, which was confirmed in the present study.

The DC of the crude protein in DDGS (827.1 $\left.\mathrm{g} \mathrm{kg}^{-1}\right)$ was close to those obtained by Graham et al. (2014a) $\left(831 \mathrm{~g} \mathrm{~kg}^{-1}\right)$ and Pedersen et al. (2007) $\left(830 \mathrm{~g} \mathrm{~kg}^{-1}\right)$. The inclusion levels of DDGS did not change the DC of crude protein, although an increase was observed in the digestible CP content of DDGS, which was promoted by the higher concentration of $\mathrm{CP}$ in the diets with greater participation of the ingredient. This finding agrees with Graham et al. (2014a) and Pedersen et al. (2007), who did not report differences in the digestibility of $\mathrm{CP}$ when comparing DDGS with corn. However, the results of the present study contrast with the findings of Wang et al. (2016), who observed a linear decrease in the DC of crude protein with an increase in DDGS from 0 to $200 \mathrm{~g} \mathrm{~kg}^{-1}$, and Agyekum et al. (2016), who observed a reduction in the digestibility of nitrogen $(\mathrm{N})$ with the inclusion of $300 \mathrm{~g} \mathrm{~kg}^{-1}$ DDGS. Our findings also disagree with Wahlstrom et al. (2013), who evaluated DDGS inclusion levels of 50 to $300 \mathrm{~g} \mathrm{~kg}^{-1}$ and found that levels above $200 \mathrm{~g} \mathrm{~kg}^{-1}$ reduced the DC of crude protein.

The DDGS inclusion to the control diet did not change the DC of ether extract, although it reduced the digestible EE content of DDGS. This observation agrees with Agyekum et al. (2016), who did not find differences in EE 
digestibility between control diet and a diet containing $300 \mathrm{~g} \mathrm{~kg}^{-1}$ DDGS. In general, the digestibility of ether extract increases as the oil content in DDGS (Graham et al., 2014b) and the dietary oil content (Kil et al., 2010) increase. Graham et al. (2014 a,b) suggested an increase in the EE digestibility of DDGS in relation to corn due to a higher dietary EE content, which did not occur in the present study. Endogenous fat losses might have led to a lower digestible EE fraction of DDGS as a result of the addition of fiber to the diets and the worsened digestibility as a whole.

Lower DE and ME values of the DDGS obtained by the chromium oxide marker method can also be observed in the comparison between the results of Gutierrez et al. (2014), who used $\mathrm{Cr}_{2} \mathrm{O}_{3}$, with those of Anderson et al. (2012), who adopted the total collection method, both evaluating the same DDGS sources. The variations between 338 and 478 $\mathrm{kcal} \mathrm{kg}^{-1}$ for DE and ME, respectively, between the methods used in the present study are close to the 261 to $678 \mathrm{kcal} \mathrm{kg}^{-1}$ for DE and 244 to $620 \mathrm{kcal} \mathrm{kg}^{-1}$ for ME observed by Gutierrez et al. (2014) and Anderson et al. (2012). Li et al. (2016) also recorded a lower energy digestibility in diets containing DDGS as determined by the marker method in comparison with total collection.

The use of the chromium oxide marker method led to lower DC and digestible fractions in relation to the total collection method for all variables. This is in line with results reported by Li et al. (2016), who observed greater digestibility of DM and nitrogen (trend) in diets evaluated by the total collection method in comparison with the titanium dioxide $\left(\mathrm{TiO}_{2}\right)$ marker method. Lower digestibility estimates observed by the $\mathrm{Cr}$ method in comparison with TC were also reported by Verussa et al. (2017) in an evaluation of glycerin for swine. The variability of results related to the $\mathrm{Cr}$ method compared with $\mathrm{TC}$ was explained by Sakomura and Rostagno (2007), who emphasized the possibility of chromium oxide not being fully retrieved in the feces, which interferes with the indigestibility factor used in the calculations of digestibility.

The DC of mineral matter in DDGS showed a high difference $\left(319.3 \mathrm{~g} \mathrm{~kg}^{-1}\right)$ between both methods. This finding may be related to the higher experimental error margin in nutrients at a low concentration in the tested ingredients because the nutrient value is calculated by difference and the analytical methods may not be precise enough to determine small nutrient concentrations (Gutierrez et al., 2014). Gutierrez et al. (2014) also stated that the partial separation of dietary fiber components and $\mathrm{Cr}_{2} \mathrm{O}_{3}$ as they flow through the digestive tract may also negatively affect the reliability in the estimate of the dietary fiber digestibility.
In this scenario, Li (2013) suggested that digestibility estimates were lower using the index method compared with the total collection method when marker recovery was below $100 \%$. According to Kavanagh et al. (2001), by using an assumed marker concentration in the diet, the marker is thought to be properly dispersed through the feed, but the marker can be lost during the mixing stage, particularly if a mill is being used. However, the concentration measured in the diet is more accurate, particularly when the same sampling procedure and laboratory analysis have been perfected over a long period to ensure accurate sampling.

\section{Conclusions}

Brazilian distillers dried grains with solubles contain 3,668 and 3,213 $\mathrm{kcal} \mathrm{kg}^{-1}$ metabolizable energy as determined by the total collection method and the chromium oxide marker technique, respectively. Levels up to $600.0 \mathrm{~g} \mathrm{~kg}^{-1}$ of the test ingredient do not influence the digestible or metabolizable energy of distillers dried grains with solubles, but compromises the digestibility coefficients of dry matter, organic matter, and neutral detergent fiber.

\section{Acknowledgments}

The authors thank Fundação de Amparo à Pesquisa do Estado de Mato Grosso (FAPEMAT), for the financial support for the research and the fellowship granted to the first author, and USIMAT Alcohol Distillery Ltda, for donating the distillers dried grains with solubles.

\section{References}

Adeola, O. and Ileleji, K. 2009. Comparison of two diet types in the determination of metabolizable energy content of corn distillers dried grains with soluble for broiler chickens by regression method. Poultry Science 88:579-585.

Agyekum, A. K.; Regassa, A.; Kiarie, E. and Nyachoti, C.M. 2016. Nutrient digestibility, digesta volatile fatty acids, and intestinal bacterial profile in growing pigs fed a distillers dried grains with solubles containing diet supplemented with a multi-enzyme cocktail. Animal Feed Science and Technology 212:70-80.

Anderson, P. V.; Kerr, B. J.; Weber, T. E.; Ziemer, C. J. and Shurson, G. C. 2012. Determination and prediction of energy from chemical analysis of corn co-products fed to finishing pigs. Journal of Animal Science 90:1242-1254.

Belyea, R. L.; Rausch, K. D.; Clevenger, T. E.; Singh, V.; Johnstond, D. B. and Tumblesonc, M. E. 2010. Sources of variation in composition of DDGS. Animal Feed Science and Technology 159:122-130.

Cerisuelo, A.; Moset, V.; Bonet, J.; Coma, J. and Lainez, M. 2012. Effects of inclusion of sorghum distillers dried grains with soluble 
(DDGS) in diets for growing and finishing pigs. Spanish Journal of Agricultural Research 10:1016-1024.

Graham, A. B.; Goodband, R. D.; Tokach, M. D.; Dritz, S. S.; Derouchey, J. M. and Nitikanchana, S. 2014a. The effects of medium-oil distillers dried grains with solubles on growth performance, carcass traits, and nutrient digestibility in growingfinishing pigs. Journal of Animal Science 92:604-611.

Graham, A. B.; Goodband, R. D.; Tokach, M. D.; Dritz, S. S.; Derouchey, J. M.; Nitikanchana, S.; and Updike, J. J. 2014b. The effects of low-, medium-, and high-oil distillers dried grains with solubles on growth performance, nutrient digestibility, and fat quality in finishing pigs. Journal of Animal Science 92:3610-3623.

Gutierrez, N. A.; Serão, N. V. L.; Kerr, B. J.; Zijlstra, R. T. and Patience, J. F. 2014. Relationships among dietary fiber components and the digestibility of energy, dietary fiber, and amino acids and energy content of nine corn coproducts fed to growing pigs. Journal of Animal Science 92:4505-4517.

Jacela, J. Y.; Frobose, H. L.; DeRouchey, J. M.; Tokach, M. D.; Dritz, S. S.; Goodband, R. D. and Nelssen, J. L. 2010. Amino acid digestibility and energy concentration of high-protein corn dried distillers grains and high-protein sorghum dried distillers grains with solubles for swine. Journal of Animal Science 88:3617-3623.

Jha, R.; Woyengo, T. A.; Li, J.; Bedford, M. R.; Vasanthan, T. and Zijlstra, R.T. 2015. Enzymes enhance degradation of the fiberstarch-protein matrix of distillers dried grains with solubles as revealed by a porcine in vitro fermentation model and microscopy. Journal of Animal Science 93:1039-1051.

Kavanagh, S.; Lynch, P. B.; O’Mara, F. and Caffrey, P. J. 2001. A comparison of total collection and marker technique for the measurement of apparent digestibility of diets for growing pigs. Animal Feed Science and Technology 89:49-58

Kil, D.; Sauber, T.; Jones, D.; and Stein, H. 2010. Effect of the form of dietary fat and the concentration of dietary neutral detergent fiber on ileal and total tract endogenous losses and apparent and true digestibility of fat by growing pigs. Journal of Animal Science 88:2959-2967.

Le Gall, M.; Warpechowski, M.; Jaguelin-Peyraud, Y.; and Noblet, J. 2009. Influence of dietary fibre level and pelleting on the digestibility of energy and nutrients in growing pigs and adult sows. Animal 3:352-359.

Li, P.; Li, D. F.; Zhang, H. Y.; Li, Z. C.; Zhao, P. F.; Zeng, Z. K.; Xu, X. and Piao, X. S. 2015. Determination and prediction of energy values in corn distillers dried grains with solubles sources with varying oil content for growing pigs. Journal of Animal Science 93:3458-3470.

Li, Y. S. 2013. Evaluation of collection method and diet effects on apparent digestibility and energy values of swine diets. Thesis (M.Sc.). University of Nebraska, Lincoln, NE.

Li, Y. S.; Tran, H.; Bundy, J. W.; Burkey, T. E.; Kerr, B. J.; Nielsen, M. K. and Miller, P. S. 2016. Evaluation of collection method and diet effects on apparent digestibility and energy values of swine diets. Journal of Animal Science 94:2415-2424.

NRC - National Research Council. 2012. Nutrient requirements of swine. 11th ed. publishing company: National Academy Press, Washington, D. C.

Pedersen, C.; Boersma, M. G.; and Stein, H. H. 2007. Digestibility of energy and phosphorus in 10 samples of distillers dried grains with solubles fed to growing pigs. Journal of Animal Science 85:1168-1176

Pedersen, M. B.; Dalsgaard, S.; Knudsen, K. B.; Yu, S.; and Lærke, H. N. 2014. Compositional profile and variation of distillers dried grains with solubles from various origins with focus on non- starch polysaccharides. Animal Feed Science and Technology 197:130-141.

Rostagno, H. S.; Albino, L. F. T.; Donzele J. L.; Gomes, P. C.; Oliveira, R. F.; Lopes, D. C.; Ferreira, A. S.; Barreto, S. L. T. and Euclides, R. F. 2011. Tabelas brasileiras para aves e suínos: composição de alimentos e exigências nutricionais. UFV, Viçosa, MG.

Sakomura, N. K. and Rostagno, H. S. 2007. Métodos de pesquisa em nutrição de monogástricos. FUNEP, Jaboticabal.

Silva, D. J. and Queiroz, A. C. 2002. Análise de alimentos: métodos químicos e biológicos. Editora UFV, Viçosa, MG.

Stein, H. H. and Shurson, G. C. 2009. Board-Invited Review: The use and application of distillers dried grains with soluble (DDGS) in swine diets. Journal of Animal Science 87:1292-1303.

Urriola, P. E.; Hoehler, D.; Pedersen, C.; Stein, H. H. and Shurson, G. C. 2009. Amino acid digestibility of distillers dried grains with soluble, produced from sorghum, a sorghum-corn blend, and corn fed to growing pigs. Journal of Animal Science 87:2574-2580.

Urriola, P. E.; Shurson; G. C. and Stein. H. H. 2010. Digestibility of dietary fiber in distillers coproducts fed to growing pigs. Journal of Animal Science 88:2373-2381.

Verussa, G. H.; Corassa, A.; Pina, D. S.; Ton, A. P. S.; Komiyama, C. M. and Teixeira, A. O. 2017. Nutritional value of glycerin for pigs determined by different methodologies. Revista Brasileira de Zootecnia 46:584-590.

Wahlstrom, R. C.; German, C. S. and George, W. L. 2013. Corn distillers dried grains with solubles in growing-Finishing swine ration. Journal of Animal Science 30:532-535.

Wang, L. F.; Beltranena, E. and Zijlstra, R. T. 2016. Diet nutrient digestibility and growth performance of weaned pigs fed wheat dried distillers grains with solubles (DDGS). Animal Feed Science and Technology 218:26-32.

Widyaratne, G. P. and Zijlstra, R. T. 2007. Nutritional value of wheat and corn distiller's dried grain with solubles: digestibility and digestible contents ofenergy, amino acids and phosphorus, nutrient excretion and growth performance of grower-finisher pigs. Canadian Journal of Animal Science 87:103-114.

Willians, C. H.; David, D. J. and Ilsmaa, O. 1962. The determination of chromic oxide in faeces samples by atomic absorption spectrophotometry. Journal Agriculture Science 59:381-385. 